Article

\title{
Upward Mobility in Education: The Role of Personal Networks Across the Life Course
}

\author{
Nicolas M. Legewie \\ Department of Sociology, University of Pennsylvania, USA; E-Mail: nlegewie@sas.upenn.edu
}

Submitted: 16 June 2021 | Accepted: 21 July 2021 | Published: 13 October 2021

\begin{abstract}
How do individuals achieve upward mobility in education despite the well-documented mechanisms that foster reproduction of inequalities? This question presents a fundamental puzzle for social science researchers and has generated an increasing body of research. The present article tackles the puzzle using a life course and personal network lens. Studying educational trajectories in Germany of students whose parents have low educational degrees, it asks: What paths did students take through the education system, what personal network factors were important for their educational attainment, and how did these factors change over students' life courses? In contrast to most studies that zoom in on a specific transition or time period, the article uses data from 36 retrospective in-depth interviews that allow a sweeping view of respondents' educational careers. Thanks to a systematic case selection scheme, the data also enables comparisons between students who became upwardly mobile and those who replicated their parents' low educational degrees. Findings suggest four types of trajectories: direct upward mobility, indirect upward mobility, direct non-mobility, and indirect non-mobility. I discuss four personal network factors that seem to drive these trajectories: support with academic efforts, encouragement, support with solving problems, and role models. Upwardly mobile students showed combinations of two or more of these four factors that established higher education as the students' goal, and provided them with tools and support to reach that goal. With these findings, the article contributes to literature on inclusion in education, social inequality and mobility, personal networks, and the life course.
\end{abstract}

\section{Keywords}

education; inclusion; life course; personal networks; upward mobility

\section{Issue}

This article is part of the issue "Promoting Inclusion and Equality in Education" edited Allen Thurston (Queen's University Belfast, UK) and Tien-Hui Chiang (Anhui Normal University, China).

(C) 2021 by the author; licensee Cogitatio (Lisbon, Portugal). This article is licensed under a Creative Commons Attribution 4.0 International License (CC BY).

\section{Introduction}

How do some individuals achieve upward mobility despite the well-documented mechanisms that foster intergenerational reproduction of inequalities? This question not only presents an important puzzle for social science researchers, it connects to the fundamental issue of social inclusion through equality of opportunity. Upward social mobility has generated an increasing body of research over the past two decades. Some studies focus on macro-level trends and the impact of structural factors, such as how rates of mobility have changed over time (Blau \& Duncan, 1967; Chetty, Hendren, Kline, Saez, \& Turner, 2014; Legewie \& Bohmann, 2018), how dif- ferences in educational institutions impact educational mobility (Alba et al., 2011; Crul, 2013), or how rates of mobility differ among regional contexts (Chetty \& Hendren, 2018; Chetty, Hendren, Kline, \& Saez, 2014). Other scholars focus on individual characteristics as factors for upward mobility, such as intelligence or other cognitive abilities (Deary et al., 2005; Heckman et al., 2006), preference for educational tracks (Breen \& Goldthorpe, 1997; Goldthorpe, 1987), or personality (Damian et al., 2015). Still others scrutinize people's social environments, where factors such as socialization within the family (Lareau, 2003), transmission of aspirations, narratives, and plans for the future (Harding, 2011; Legewie, 2016), or access to social support and cultural 
knowledge (Lareau, 2015; Stanton-Salazar, 2001) have been key concerns. This article focuses on such social environment factors for understanding upward educational mobility.

I study educational trajectories of disadvantaged students in Germany. With "disadvantaged," I mean that students' parents had low to medium educational degrees and no experiences in higher education. I ask: What paths did students take through the education system, what personal network factors were important for their educational attainment, and how did these factors change over students' life courses? The article uses data from 36 retrospective in-depth interviews that allow a sweeping view of respondents' educational careers, in contrast to most studies that zoom in on a specific transition or time period. Interviews were conducted in Berlin, Germany, which comprises an ideal context for studying upward mobility because it represents a least-likely scenario (see Section 2.2).

My findings suggest four types of trajectories: direct upwardly mobility, indirect upward mobility, direct nonmobility, and indirect non-mobility. I discuss four personal network factors that seem to drive these trajectories: support with academic efforts, encouragement, support with solving problems, and role models. My analysis of these factors over time suggests that there is considerable variation in the extent to which students have access to network-based resources, and timing of that access vis-à-vis choices, events, and transitions plays an important role in whether students can use resources on their way to upward educational mobility and inclusion.

\section{Literature Review}

\subsection{Upward Educational Mobility, Personal Networks, and the Life Course Perspective}

A fruitful perspective for exploring the impact of social environments on upward mobility are personal networks, which focus on an individual's social relations with others. From this perspective, the question of why some people achieve upward mobility can be answered by looking at (1) the network structure, i.e., the configurations of social relations that make up a personal network, and (2) network content, i.e., the knowledge, skills, and world views that alteri bring into the network.

Research on network structure has focused on the size of the personal network and its impact on mobility (Lin et al., 1999), whether ties provide bridges between usually separate networks and thus give access to new information or resources (Granovetter, 1973; Wuthnow, 2002), and density of personal networks, which increases the cohesiveness of norms and values virulent in a network and may thereby foster upward mobility (Coleman, 1988; Fasang et al., 2014; Morgan \& Sørensen, 1999).

Regarding content in personal networks, crucial dimensions for upward social mobility are material resources (Kibria, 1994; Portes \& Fernández-Kelly, 2008, p. 22), academic and cultural knowledge (Crul, 2013, p. 63; Lareau, 2015), goal orientations, interpretations, and modeling behavior (Harding, 2011; Kao \& Tienda, 1998; Legewie, 2016), and recognition and emotional support (Malecki \& Demaray, 2003; Stanton-Salazar \& Spina, 2005). By transmitting such diverse kinds of content, most types of social relations, such as family and peer relations, can either foster or hamper upward mobility (Lareau, 2003, pp. 165-181; Ream \& Rumberger, 2008; Sokatch, 2006). Formal and informal mentors have received special attention because they provide ego with access to knowledge and resources otherwise unavailable to them (Crul, 2002; Erickson et al., 2009; Stanton-Salazar \& Spina, 2003).

Using these two facets as analytical lenses, scholars have described how personal network factors, which usually contribute to reproducing inequalities, can sometimes be connected to upward educational mobility. For instance, parents with low educational degrees can usually provide less help in their children's educational careers. Still, such parents sometimes contribute to their children's upwardly mobile trajectories, e.g., by close parental monitoring to maintain children's focus on education (Jarrett, 1995, pp. 122-123; Maton et al., 1998, p. 651) or by investing scarce family resources to provide children with support in their schooling (Ceballo, 2004, p. 176; Modood, 2011, p. 476; Portes \& Fernández-Kelly, 2008, p. 22). In a similar way, peer networks usually contribute to inequalities because students from low-status families have less college-bound peers in their network (Sokatch, 2006). However, peer networks can still foster upward educational mobility if they are composed of students with a strong focus on education (Ream \& Rumberger, 2008; Smith, 2014). A third set of personal network factors contributing to upward educational mobility are bridging ties (Granovetter, 1973; Putnam, 2007, p. 143); what others call "horizon-expanding ties" (Morgan \& Sørensen, 1999) or "brokers" (Burt et al., 2001). Bridging ties connect a person to someone who provides access to knowledge, strategies, and resources otherwise unavailable to them; e.g., people from different socio-economic backgrounds. Disadvantaged students can get access to bridging ties through avenues such as older siblings (Bettie, 2002, p. 413; Crul, 2013, p. 62), mentoring (Grossman \& Tierney, 1998; Langhout et al., 2004; McDonald \& Lambert, 2014), and ethnically bounded, status-diverse, institution-based networks (Bankston \& Zhou, 1996; Kasinitz et al., 2008, pp. 171, 347-348; Zhou \& Kim, 2006).

As this overview shows, network theory suggests multiple ways in which personal networks may foster educational attainment and upward mobility. But because studies of upward educational mobility often focus their analysis exclusively on upwardly mobile participants (e.g., El-Mafaalani, 2012; Farrokhzad, 2010; Raiser, 2007; Tepecik, 2011), they may identify personal network factors that form a trivial part of explanations of upward mobility. Such factors seem to be relevant 
because they appear in upwardly mobile participants' accounts of their educational careers, but in fact the same factors are present in educational careers of people who did not become upwardly mobile. My article addresses this issue by employing a structured case selection that enables systematic cross-case comparisons.

A further contribution of this study is its holistic, lifecourse view of educational careers. Upward educational mobility is a process that spans twenty to thirty years. Hence, instead of studying specific episodes or isolated educational decisions, the life course perspective suggests to focus on processes over a long time (Elder, 1985; Mayer, 2009, p. 414) and be mindful of turning points during the life course (Legewie \& Tucci, 2021). In this article, I take a sweeping view of upward mobility in education, which allows me to describe different educational trajectories of upward mobility and non-mobility, identify relevant personal network factors looking at entire educational careers instead of discrete decisions, phases, or transitions, and analyze the importance of timing of personal network factors vis-à-vis events and transitions during educational careers.

\subsection{The German Educational System}

Compared to other educational systems, the German educational system stands out regarding three characteristics that affect disadvantaged students' inclusion. First, contact hours are limited, i.e., students spent less time in school (Alba et al., 2011, p. 402f). Schools provide a relatively homogeneous learning environment, compared to other contexts such as the family (Cooper et al., 1996; Downey et al., 2004). Thus, students from disadvantaged backgrounds profit from school systems in which students spend more time in school in terms of the duration of the school day and summer vacation. Although primary schools with full-day programs have become much more common in recent years, this change did not affect any of the respondents in my study because they attended school before that change took effect.

Second, Germany has a "dual" educational system, with a general education track and a vocational school track. In contrast to many other societies, in Germany learning a vocation is highly formalized, with institutions and their curricula and exams regulating entry to many professions. This characteristic is relevant because the vocational branch of the education system promises a quick transition into the labor market, and studies show that students from low socio-economic backgrounds often decide against higher education and instead opt for vocational training (Becker \& Hecken, 2009).

A third important characteristic is tracking, which refers to mechanisms through which education systems sort students into different school types or classes according to their prior performance. Tracking practices differ in terms of timing and rigidity (Alba et al., 2011), and in Germany, it happens early (around age twelve), is highly formalized, and quite rigid (Alba et al., 2011, p. 401; Ditton, 2008, p. 250). For readers unfamiliar with the different tracks of the German education system, Supplementary File S1 provides a brief description, as well as an illustration. Important to note here is that to access higher education, students have to earn the Abitur, a degree from a higher-tier secondary school. The most common way to do so is to get tracked into such a school at the transition from primary to secondary school, at age twelve in most Berlin schools. A further way to earn the Abitur is through vocational secondary schools or night schools that operate as second-chance routes to higher education.

Because of these three characteristics, the German educational system can be seen as a least-likely scenario for upward educational mobility, and thus offers especially interesting analytical leverage (Gerring, 2008, p. 659); personal network factors relevant here are more likely to play an important role in educational careers elsewhere, too.

\section{Data and Methods}

I draw on a data set of 36 in-depth interviews from a study on educational attainment among former students in Berlin, Germany. My data set includes only respondents from families whose parents both had low educational degrees (at most ten years of general education). To ensure comparative leverage, I included 24 cases of upward mobility and twelve cases of non-mobility. "Upward mobility" refers to students who earned at least a Bachelor's degree; "non-mobility" is defined as everything below a Bachelor's degree. Supplementary File S2 provides an overview table of cases in my data set. One respondent in the non-mobile group had enrolled in a law program by the time of the interview, and was hence treated as an upward mobility case, leading to a final data set of 25 upwardly mobile and eleven non-mobile cases.

To collect data for this study, I used in-depth retrospective interviewing, which enables reconstructing educational careers as well as the role of personal networks during those careers (see Supplementary File S3 for a brief discussion of challenges in retrospective interviewing). Interviews focused on a diverse array of topics that I tracked along respondents' life courses, including respondents' educational careers, family backgrounds, as well as their personal networks. Although I used a list of topics and follow-up questions as an interview guide (see Supplementary File S4), the interviews were unstructured in that the respondents were able to guide the conversation based on their interests and recollections.

I used qualitative data analysis software (ATLAS.ti v.8.1) to code all 36 interviews (see Supplementary File S5 for the list of codes). My findings are based on three analytic steps. First, I reconstructed respondents' educational careers, using a case-centered analytic approach (e.g., George \& Bennett, 2005; Lareau, 2015) and treating educational careers as sequences of decisions, events, and crucial phases and transitions (Elder et al., 2003). 
The result from this analytic step are detailed case reconstructions that form the basis of the trajectory types I present in Section 4.1. Second, I used withinand cross-case comparisons to analyze relevant social ties and personal networks, and conceptualize ways in which ties may have impacted respondents' educational careers. This analysis produced the four types of personal network factors of upward educational mobility that I discuss in Section 4.2. Third, I analyzed the broader patterns of connection between personal network factors and upward educational mobility in my data set, using simple co-occurrence tables. While such tables do not provide representative findings, they can structure the analysis by showing overall patterns, as well as cases deviating from those patterns. The co-occurrence tables also suggest that none of the identified factors can explain upward educational mobility by themselves. Rather, they may be understood as positive "risk factors" that increase the chances that students achieve upward mobility. To illustrate the patterns in my data, I will provide numbers from these co-occurrence tables when discussing each personal network factor.

\section{Findings}

\subsection{Educational Trajectories}

The educational trajectories I found can be grouped into four different types, based on their outcome (student earned degree in higher education or not) and the route traveled (a straight line or an indirect route). "Straight line" refers to the normative and institutionalized "com- mon route" to university or an early labor market entry. "Indirect route" refers to deviations from such default routes. Figure 1 illustrates the four trajectory types.

The straight-line upward trajectory includes respondents who went from primary school to higher-track secondary schools and on to university, with a maximum gap of one year between these steps (e.g., the formerly mandatory German civil or military service, a year spent abroad as an au-pair, or working before starting university studies). Most of these respondents went to a university, while some chose a technical college (Fachhochschule) or a dual program offering a combination of university studies and work experience. Most respondents in this type had no major problems in school and earned above-average grades throughout their school careers, while some completed this trajectory despite severe difficulties. Seventeen of the 25 respondents who were upwardly mobile showed this trajectory.

The indirect upward trajectory includes respondents who made their way to higher education through secondchance educational programs. Their trajectory involved at least one turning point, in the course of which the respondents decided to abandon their trained profession or job and go back to school. Eight out of 25 respondents showed such an indirect upward trajectory.

The straight-line non-mobility trajectory describes respondents who did not enter higher education but instead earned a low or intermediate educational degree, and did so through a direct route. From primary school, these respondents entered non-university-track secondary schools, and went on to a vocational training

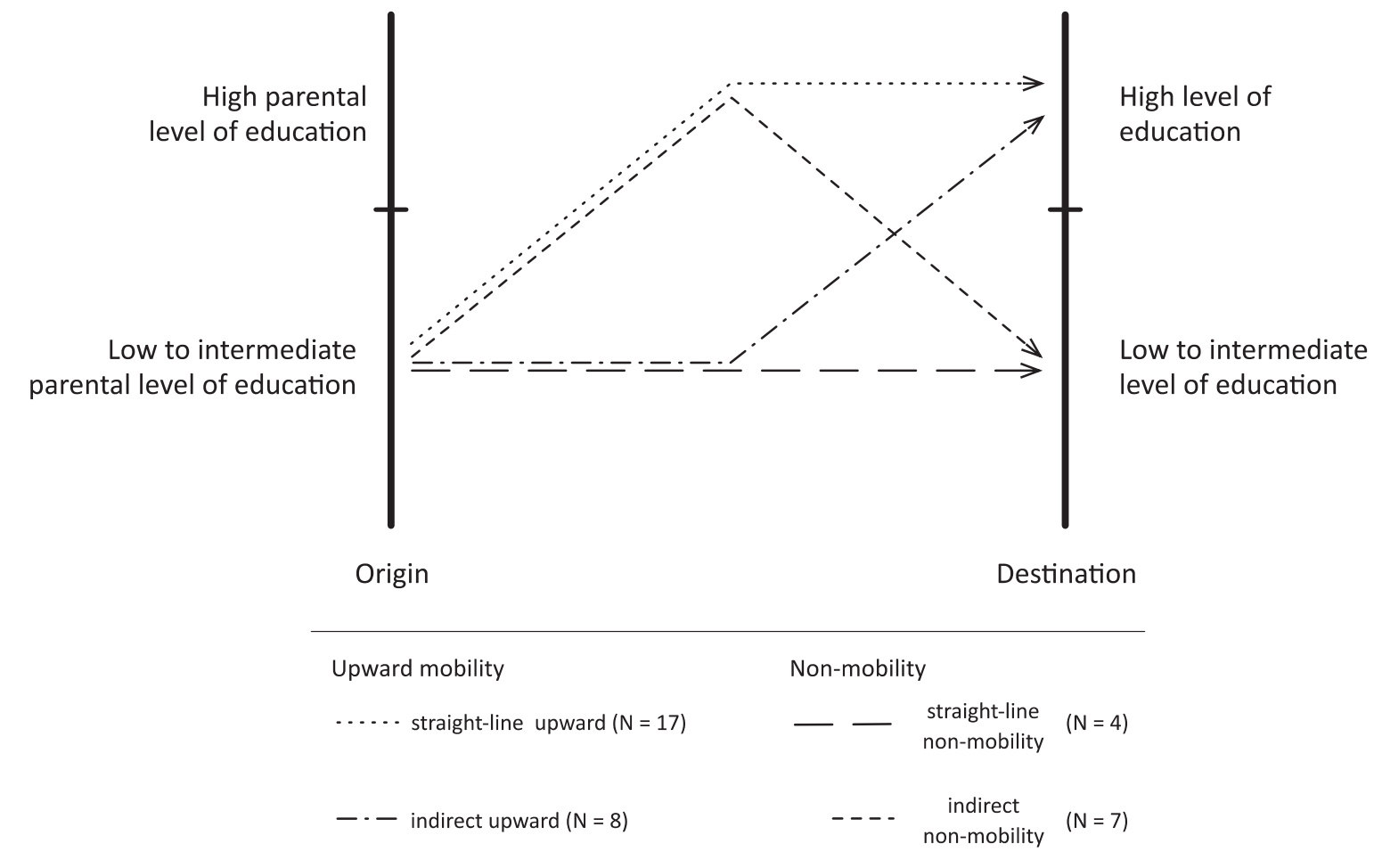

Figure 1. Educational trajectories. 
and/or the labor market. Some of these respondents considered going to university, while others never thought about this option. Out of the eleven respondents in my data set who were non-mobile, four showed this straightline non-mobility trajectory.

Finally, the indirect non-mobility trajectory describes respondents who did not earn a higher educational degree, but were en route to do so at some point. Through a turning point their trajectory took a downward swing. Seven out of eleven non-mobile respondents in my data set showed this trajectory. This is especially interesting because these students passed the initial hurdle of being tracked into university-track secondary schools, but were unable to follow this route all the way to higher education.

\subsection{Personal Network Factors and Upward Educational Mobility}

In the following, I discuss four personal network factors that, according to my in-depth case analysis and crosscase comparisons, played important roles in upwardly mobile students' educational careers across their life courses: support with academic efforts, encouragement, support with solving problems, and role models. These four factors provide either orientation for what goals to pursue, or concrete know-how or support for how to achieve these goals. In this sense, they provide complementary resources and advantages that help disadvantaged students becoming upwardly mobile, especially in their combination. I will expand on each factor in turn, using brief case descriptions to illustrate broader patterns present across my data set.

\subsubsection{Support with Academic Efforts}

With support with academic efforts, I refer to help respondents received from any tie in their personal network, which targeted directly the respondents' responsibilities in school; i.e., homework and studying for exams. Examples are respondents working through homework assignments with their parents, or teachers providing extra tutoring after school. Such support is mundane for students from affluent families, which they receive mainly through their parents. In contrast, for disadvantaged students access to such support is often scarce and thus crucial for educational upward mobility because their parents often cannot support them in school. In my data set, 16 out of 25 upwardly mobile respondents had received strong support with academic efforts. Among non-mobile students, the ratio was three out of eleven respondents.

Support with academic efforts that mattered in cases in my data set came in three different categories. Sometimes, it was about correcting mistakes. Other times, support came in the form of explaining difficult content. Some parents who could afford to do so organized a paid tutor for their child, as Natascha describes:
"I had tutoring in physics, from seventh to ninth grade. And through that I saw that I could actually get it. That was this really nice guy, a neighbor, he explained everything really well." In yet other cases, support took the form of showing strategies. Umut, who graduated from a fine arts university program, explains:

I chose history as an advanced class for Abitur. And [the principal] really helped me with that. He showed me how to structure an essay and things like that.... What quotes to choose to learn for an exam. You know in advance what the topic of the exam will be. So he showed me how to pick the right literature.

An important aspect was whether support was stable throughout respondents' educational trajectories. This is not trivial because students moved through different life stages that entailed changes in institutional demands and personal network composition (Bidart \& Lavenu, 2005; Mayer, 2004, p. 163). This dependence on life course stages made support with academic efforts fragile. The passing of time and change of demands affected the support respondents received with their academic efforts in two ways. First, in primary school parents were often a vital source of support with academic efforts for respondents. However, as respondents progressed through the education system, this support tended to fizzle out. After primary school, or the first years of secondary school at the very latest, respondents had surpassed their parents in the years they attended school and the material they learned. Thus, the parents lost the ability to provide substantial help. In addition, some parents lost their ability to pay for professional tutoring (while others were not able to do so in the first place).

A second way in which support with academic efforts was fragile to the change of life stages was because such changes can sever ties to non-family supporters such as teachers, other non-family adults, or peers. One way this happened was through changing contexts of interaction. As students changed schools, the ties established to supportive teachers usually did not persist. As a result, respondents showed different patterns of support with academic efforts over their educational careers. Some had constant support from a stable set of ties; others had constant support, but from a changing set of ties. Still others did not have constant support, but received support during crucial moments or transitions. And finally, some respondents received little or no support with academic efforts after primary school. In line with expectations, the latter mostly applied to non-mobile respondents.

\subsubsection{Encouragement}

With Encouragement, I refer to ties in a respondent's personal network communicating approval for that respondent's accomplishments or providing them with comfort in the face of setbacks. Encouragement fostered 
upward educational mobility in my data set by helping to set high educational goals, reinforcing upwardly mobile trajectories, or resetting non-mobility trajectories to a route to upward mobility. In my data set, 19 out of 25 upwardly mobile cases received strong encouragement during their educational careers, compared to three out of eleven non-mobile cases.

To understand the role of encouragement, consider the case of Hamit, a 29-year-old MA student of economic engineering. Hamit faced a crucial period in his young life around the age of 17. After a conflict-ridden time in primary and secondary school, he had found a vocational training position, but failed the first year. In fact, he was on the brink of being expelled from the program. At the same time, he was facing serious trouble in his private life. For a while he had been stealing car radios with his closest friends to have more spending money.

A key factor in Hamit's turn-around was positive feedback and reassurance he received from his job supervisor, Ahmed. Hamit met Ahmed through Hamit's sister, who was working for Ahmed as a tutor. Ahmed helped Hamit with a math problem from school and told him to come back any time he needed help. Soon, he offered Hamit a job and a close relationship began to form. At the core of this relationship was a brotherly affection Hamit felt for Ahmed; an affection that was fed by Ahmed's constant expressions of faith in Hamit's abilities and positive future. Hamit elaborates:

Our relationship became closer, somehow. He became like family. I felt at home with him.... He wanted me to show people that I wasn't a loser.... He kept telling me: “I'm so happy that you do this [getting the Abitur]. Don't let anyone drag you down. You have great potential." And to keep hearing things like that, that's just great.

After having finished his vocational training, Hamit faced several stages at which he had to choose between entering the labor market or pursuing further education: after his vocational training, after graduating from a secondchance Abitur institution, and upon finishing his BA degree. At each stage, entering the labor market would have seemed like the easier, more obvious choice, given Hamit's earlier experiences with the education system. His supervisor's encouragement played an important role in defining higher educational degrees as the goal to pursue, and making them seem attainable for Hamit:

I'm really indebted to him, he was one of the key people who pushed me to enter university. He kept motivating $\mathrm{me}$, and just wanted.... He had a vision for me, let's put it that way. He believed more in me than I believed in myself. He kept pushing me.

Importantly, the positive influence of encouragement depends on its timing vis-à-vis crucial phases in respondents' trajectories. The case of Jochen, a 31-year-old student of psychology, illustrates this point. Jochen grew up with his parents and his two half-sisters in a lower-income neighborhood in the northeast of Berlin's inner city in the former GDR. His parents had both graduated from Realschule and completed a vocational training. After German reunification, when Jochen was six years old, both parents lost their jobs and remained unemployed.

Throughout primary and secondary school, Jochen was an able student (he even was outstanding in chemistry), but pursuing the Abitur or higher education was never a topic. This is not surprising from a personal network perspective, since neither his family relations nor his school peers transmitted such an education as a goal. For instance, recalling the transition to secondary school, Jochen states:

Back then we had to show all exams to our parents. And they said: "Good." But that wasn't really a big deal. [With a bad grade,] they said: "Well, you could have done more," or "Next time might be better." But those things didn't really matter....Choosing a school was a practical question. There's a school, that's the closest. Done. There was no "you should definitely get the Abitur," or anything.

Jochen did receive strong encouragement from a teacher during lower secondary school, which could have served as a reset of his trajectory. However, this encouragement came after Jochen had already decided to enter vocational training. The encouragement thus did not lead him to attempt earning the Abitur after his graduation:

And she thought it was, she felt a little disappointed at the end of tenth grade, that I started a vocational training and did not try the Abitur. [During the graduation party] she said: "We are looking for a certain someone who could have a chance to earn the Nobel prize in chemistry [laughs], but who decided to start his professional career." Something like that.... She just felt a little disappointed, that I kind of...that I didn't pursue my talent.

Instead, Jochen started a vocational training. As this example illustrates, misalignment of encouragement and institutional transitions can curtail the positive impact of encouragement.

\subsubsection{Solving Problems}

The concept of solving problems refers to situations in which ties in a respondent's personal network took care of a problem that would otherwise have jeopardized that respondent's educational attainment. Examples are a teacher preventing incipient expulsion from school, or a supervisor at work accommodating a student's need for flexible work hours to enable that student to remain in school while earning an income. Eleven 
out of 25 upwardly mobile respondents in my data set showed at least one incident of someone solving a problem crucial for the respondent's educational advancement. Among non-mobile students, this only happened in one case.

The problems to be solved took many forms in the cases in my data set, ranging from conflicts with teachers or peers, to administrative issues, to balancing school and work needs, to incipient disciplinary sanctions. Respondents received support with solving these problems in the form of intervention, mediation, or bending the rules. The people providing this support were either influential insiders (often teachers) or expert outsiders (for instance, government agency professionals or weak ties through organizational networks).

To illustrate the impact solving problems can have, consider the case of Dilara, daughter of Turkish-born parents. Dilara grew up with five older siblings (four brothers, one sister) in the south-eastern part of Berlin. In 1995, when Dilara was eight years old, her father suffered a heart attack that forced him into early retirement and plunged the family into poverty. The mother became the family's sole breadwinner until Dilara's older siblings were able to contribute to the family income. Among other factors, a teacher solving a crucial problem in school was key for Dilara's upwardly mobile trajectory. During her last year of secondary school, in the preparatory phase for the Abitur, Dilara was in conflict with her history teacher. This conflict was especially problematic because Dilara had to write an important final exam that this teacher was to grade. The grades she would receive for those exams, in turn, would greatly influence her final grade point average and, by extension, her ability to enroll in her preferred academic career. A teacher helped Dilara with her studying efforts by advising her on her outline. However, the more crucial support in this episode was the teacher's willingness to step in as Dilara's examiner. In doing so, he prevented Dilara's exam grade to be subject to the good will of a teacher who, as Dilara recalls, clearly disliked her.

In contrast, consider the following account of Balcan, a 36-year-old office clerk, who also had a conflict with a teacher, but who had no one solving this problem:

That teacher, he had some strange notions. I think we were talking about the Nazi regime or something.... Well, and since I'm a foreigner and he's German, it was something about that. We had a real fight, during class. And I felt really offended and went to the principal after class. He really liked me and also knew my parents. I felt safe there. So I went to him and complained. I think I even cried because that had really disturbed me.... So the principal talked to the teacher, and after that he called me in again. And he said that I must have misunderstood something. He tried to calm me down. But the problem stayed, nothing changed. So I stopped going to that class.
Balcan describes how she collided with her teacher because of the teacher's "strange notions" regarding the Nazi era and Balcan's background. Her teacher's attitudes, which she perceived as racist, deeply disturbed her. The example illustrates how two members of an institution (a teacher in Dilara's case, the principal in Balcan's case) were in similar situations in that they were presented with the problem of a student. In Dilara's case, the teacher took measures that solved the problem, thus disposing of an obstacle that was complicating Dilara's successful graduation. In Balcan's case, the principal took measures that did not solve the problem, but rather tried to appease Balcan. Ultimately, this tepid response led to the conflict becoming a major obstacle between Balcan and her graduation.

\subsubsection{Role Models}

With "role models" I refer to a person admired and imitated by a respondent. Role models fostered upward educational mobility either by setting educational goals and reinforcing an internal locus of control, or by providing examples of specific positive strategies, skills, or behavioral patterns respondents imitated. Among upwardly mobile respondents, 13 of 25 showed a role model important for their educational careers, in contrast to only one example out of the eleven non-mobile students.

A case example can illustrate the impact role models had on some respondents' educational trajectories. Melanie had her future figured out. After finishing the intermediate maturity degree at a comprehensive school, she would spend a year abroad as an au-pair before starting her vocational training as a bookseller. In her cohort in secondary school, the prevalent topic of discussion was not whether to go on to upper secondary school or do a vocational training; peers only talked about which vocational training to choose:

I attended a comprehensive school, and there were only three people out of 30 students who wanted to do the Abitur. Nobody even talked about going to university. When we talked about what we wanted to do, nobody said "lawyer" or something like that. It was about jobs like florist, midwife, or nurse. Even though I had good grades and could have gone to get my Abitur, that didn't even occur to me.

Melanie describes a crucial transition in her educational trajectory: After tenth grade, most of her peers decided to start a vocational training instead of going for the Abitur. The quote illustrates how Melanie's personal network, through the conversations in her peer group and the choices those peers made, played an important part in her decision to also start a training ("even though I had good grades and could have gone to get my Abitur, that didn't even occur to me").

Melanie's plans changed dramatically during her stay as an au pair in Venezuela. In this new environment, her 
friends were mostly university students, and she came to envy their seemingly carefree, independent life. More importantly, her host was an immigrant from Colombia whose parents had worked as taxi drivers. The host had earned a university degree and now owned several businesses and worked as a motivation coach for business managers. In him, Melanie saw embodied the rewards of a good education: moving up the social ladder and working in an interesting job that grants personal freedom:

He worked hard to move up, mainly through his university education. He had several businesses, and he obviously enjoyed his work. I found that fascinating.... My decision to go to university-track secondary school was definitely linked to Venezuela. Because the country is very much about the differences between rich and poor, that divide. And I felt like the only chance to move up was through education.

Melanie's role model relation to her host captures perfectly how a role model can open an entire new horizon of possibilities and thus can profoundly change educational trajectories, especially during transitions. Melanie's choice to do an au pair year in Venezuela at the age of 16 might be uncommon and therefore the circumstances of her meeting her role model may seem idiosyncratic. But young students can meet people who inspire them in countless ways, many of which are much more mundane than the example of Melanie. The other cases in my data set are testimony to that, with respondents describing their parents, teachers, siblings, soccer coaches, or extended family members as role models.

\section{Conclusions}

This article studied educational trajectories in Germany of students whose parents have low educational degrees, in order to understand what paths students took through the education system, what personal network factors were important for their educational attainment, and how these factors changed over students' life courses. The article used data from 36 retrospective in-depth interviews for a sweeping view of respondents' educational careers. Findings suggest four types of trajectories: direct upwardly mobility, indirect upward mobility, direct non-mobility, and indirect non-mobility. I described four personal network factors that seemed to drive these trajectories: support with academic efforts, encouragement, support with solving problems, and role models. These four factors provided either orientation for what goals to pursue, or concrete know-how or support for how to achieve these goals. In this sense, they comprise complementary resources and advantages that, especially in their combination, help students to become upwardly mobile. There was considerable variation in the extent to which students had access to network-based resources, and timing of that access vis-à-vis choices, events, and transitions played an impor- tant role in whether students could use resources on their way to upward educational mobility and inclusion.

The findings enable an interesting perspective on inclusion in the German educational system and beyond. As I described in this article, students whose parents have low educational degrees require specific resources to achieve upward educational mobility. However, beyond the mere provision of such resources through personal network ties, the timing of resource provision is crucial, which allows us to ask: Are schools aware of the needs of disadvantaged students, as well as the timing of when resources are especially needed? For instance, in the German educational system the transition from primary to secondary school is pivotal. Disadvantaged students who are able to enter universitytrack schools face additional challenges because after the transition, demands of schools on student performance increase, but parental support often decreases because parents may not be able to support their children with the more advanced class material. At the same time, secondary schools and their teachers often provide less support to students compared to primary schools. These parallel developments present additional challenges to disadvantaged students that can lead to them failing to complete their upward route, as the trajectory types discussed in this article have shown. Said challenges may be addressed systematically, e.g., through appropriate public support programs. Reform could create support programs that take into account demands of the school curriculum, students' needs, as well as typical changes in personal network support over time. Further research could explore this critical juncture in more detail.

Future research may also build on the presented findings using complementary methodological approaches. The retrospective in-depth interviews approach I used in this study provided a good balance between detailed data and comparative leverage, but it has limitations. First, respondents' accounts of events and circumstances long past may be tinged by recall bias and active construction and re-interpretation of memories. Second, retrospective accounts do not allow for causal analyses of the connection between personal network factors and upward educational mobility. Third, it is unclear whether findings from my study generalize beyond cases in my data set. To address these limitations, future studies could employ ethnographic revisit studies (Smith, 2006) to allow for recurrent hypothesis testing and theory development. Another fruitful avenue is to employ a longitudinal survey approach in order to test generalizability of my findings to the population level.

With these and other options, research on upward educational mobility that studies the role of personal network factors from a life-course perspective promises to add important insights to our understanding of social mobility and inclusion in education. 


\section{Acknowledgments}

The author would like to thank Maurice Crul, Klaus Eder, Anette Fasang, Annette Lareau, and Anne Nassauer for their support in conducting this study and for feedback on the manuscript. In addition, the author would like to thank the two anonymous reviewers who provided helpful and insightful suggestions for revisions. The author is indebted to the Fritz Thyssen Foundation for supporting a research stay at University of Pennsylvania, during which part of this article was written. The Foundation also provided funding for the open access publication of this article. Special thanks go to the participants of the study, without whom this research could not have been realized.

\section{Conflict of Interests}

The author declares no conflict of interests.

\section{Supplementary Material}

Supplementary material for this article is available online in the format provided by the author (unedited).

\section{References}

Alba, R. D., Sloan, J., \& Sperling, J. (2011). The integration imperative: The children of low-status immigrants in the schools of wealthy societies. Annual Review of Sociology, 37, 395-415.

Bankston, C. L., III, \& Zhou, M. (1996). The ethnic church, ethnic identification, and the social adjustment of Vietnamese adolescents. Review of Religious Research, 38(1), 18-37.

Becker, R., \& Hecken, A. E. (2009). Higher education or vocational training? Acta Sociologica, 52(1), 25-45.

Bettie, J. (2002). Exceptions to the rule upwardly mobile white and Mexican American high school. Gender \& Society, 16(3), 403-422.

Bidart, C., \& Lavenu, D. (2005). Evolutions of personal networks and life events. Social Networks, 27(4), 359-376. https://doi.org/10.1016/j.socnet.2004.11. 003

Blau, P. M., \& Duncan, O. D. (1967). The American occupational structure. Wiley.

Breen, R., \& Goldthorpe, J. H. (1997). Explaining educational differentials. Rationality and Society, 9(3), 275-305.

Burt, R., Cook, K., \& Lin, N. (Eds.). (2001). Social capital: Theory and research. de Gruyter.

Ceballo, R. (2004). From barrios to Yale: The role of parenting strategies in Latino families. Hispanic Journal of Behavioral Sciences, 26(2), 171-186.

Chetty, R., \& Hendren, N. (2018). The impacts of neighborhoods on intergenerational mobility I: Childhood exposure effects. The Quarterly Journal of Economics, 133(3), 1107-1162. https://doi.org/ 10.1093/qje/qjy007

Chetty, R., Hendren, N., Kline, P., \& Saez, E. (2014). Where is the land of opportunity? The geography of intergenerational mobility in the United States. The Quarterly Journal of Economics, 129(4), 1553-1623. https://doi.org/10.1093/qje/qju022

Chetty, R., Hendren, N., Kline, P., Saez, E., \& Turner, N. (2014). Is the United States still a land of opportunity? Recent trends in intergenerational mobility. American Economic Review, 104(5), 141-147. https://doi. org/10.1257/aer.104.5.141

Coleman, J. S. (1988). Social capital in the creation of human capital. The American Journal of Sociology, 94, 95-120.

Cooper, H., Nye, B., Charlton, K., Lindsay, J., \& Greathouse, S. (1996). The effects of summer vacation on achievement test scores: A narrative and meta-analytic review. Review of Educational Research, 66(3), 227-268. https://doi.org/10.2307/ 1170523

Crul, M. (2002). Success breeds success. Moroccan and Turkish student mentors in the Netherlands. International Journal for the Advancement of Counselling, 24, 275-287. https://doi.org/10.1023/ A:1023324914148

Crul, M. (2013). Snakes and ladders in educational systems: Access to higher education for secondgeneration Turks in Europe. Journal of Ethnic and Migration Studies, 39(9), 1383-1401.

Damian, R. I., Su, R., Shanahan, M., Trautwein, U., \& Roberts, B. W. (2015). Can personality traits and intelligence compensate for background disadvantage? Predicting status attainment in adulthood. Journal of Personality and Social Psychology, 109(3), 473-489. https://doi.org/10.1037/pspp0000024

Deary, I. J., Taylor, M. D., Hart, C. L., Wilson, V., Smith, G. D., Blane, D., \& Starr, J. M. (2005). Intergenerational social mobility and mid-life status attainment: Influences of childhood intelligence, childhood social factors, and education. Intelligence, 33(5), 455-472. https://doi.org/10.1016/j.intell.2005.06.003

Ditton, H. (2008). Der Beitrag von Schule und Lehrern zur Reproduktion von Bildungsungleichheit [The impact of schools and teachers on the reproduction of educational inequalities]. In R. Becker \& W. Lauterbach (Eds.), Bildung als Privileg [Education as privilege] (pp. 247-275). Springer.

Downey, D. B., von Hippel, P. T., \& Broh, B. A. (2004). Are schools the great equalizer? Cognitive inequality during the summer months and the school year. American Sociological Review, 69(5), 613-635.

Elder, G. H. (1985). Life course dynamics: Trajectories and transitions, 1968-1980. Cornell University Press.

Elder, G. H., Kirkpatrick Johnson, M., \& Crosnoe, R. (2003). The emergence and development of life course theory. In J. T. Mortimer \& M. J. Shanahan (Eds.), Handbook of the life course (pp. 3-19). Springer. 
El-Mafaalani, A. (2012). Bildungsaufsteigerlnnen aus benachteiligten Milieus: Habitustransformation und soziale Mobilität bei Einheimischen und Türkeistämmigen [The upwardly mobile from disadvantaged milieus in education: formation of habitus and social mobility among natives and descendants of Turkish migrants]. Springer.

Erickson, L. D., McDonald, S., \& Elder, G. H. (2009). Informal mentors and education: Complementary or compensatory resources? Sociology of Education, 82(4), 344-367. https://doi.org/10.1177/ 003804070908200403

Farrokhzad, S. (2010). Erfahrungen, Strategien und Potenziale von Akademikerinnen mit Migrationshintergrund. [Experiences, strategies, and potentials of academics from migrant families]. In G. Hentges, V. Hinnenkamp, \& A. Zwengel (Eds.), Migrations- und Integrationsforschung in der Diskussion: Biografie, Sprache und Bildung als zentrale Bezugspunkte [Migration and integration research in dialogue: Biography, language, and education as points of reference] (2nd ed.). Springer.

Fasang, A. E., Mangino, W., \& Brückner, H. (2014). Social closure and educational attainment. Sociological Forum, 29(1), 137-164. https://doi.org/10.1111/ socf.12073

George, A. L., \& Bennett, A. (2005). Case studies and theory development in the social sciences. MIT Press.

Gerring, J. (2008). Case selection for case-study analysis: Qualitative and quantitative techniques. In J. M. Box-Steffensmeier, H. E. Brady, \& D. Collier (Eds.), The Oxford handbook of political methodology ( $\mathrm{pp}$. 645-684). Oxford University Press.

Goldthorpe, J. H. (1987). Social mobility and class structure in modern Britain (2nd ed.). Oxford University Press.

Granovetter, M. S. (1973). The strength of weak ties. The American Journal of Sociology, 78(6), 1360-1380.

Grossman, J. B., \& Tierney, J. P. (1998). Does mentoring work? An impact study of the Big Brothers Big Sisters program. Evaluation Review, 22(3), 403-426. https://doi.org/10.1177/0193841X9802200304

Harding, D. J. (2011). Rethinking the cultural context of schooling decisions in disadvantaged neighborhoods. From deviant subculture to cultural heterogeneity. Sociology of Education, 84(4), 322-339. https://doi. org/10.1177/0038040711417008

Heckman, J. J., Stixrud, J., \& Urzua, S. (2006). The effects of cognitive and noncognitive abilities on labor market outcomes and social behavior. Journal of Labor Economics, 24(3), 411-482. https://doi.org/10.1086/ 504455

Jarrett, R. L. (1995). Growing up poor: The family experiences of socially mobile youth in low-income African American neighborhoods. Journal of Adolescent Research, 10(1), 111-135.

Kao, G., \& Tienda, M. (1998). Educational aspirations of minority youth. American Journal of Education,
106(3), 349-384.

Kasinitz, P., Mollenkopf, J. H., Waters, M. C., \& Holdaway, J. (2008). Inheriting the city: The children of immigrants come of age. Harvard University Press.

Kibria, N. (1994). Household structure and family ideologies: The dynamics of immigrant economic adaptation among Vietnamese refugees. Social Problems, 41(1), 81-96. https://doi.org/10.2307/3096843

Langhout, R. D., Rhodes, J. E., \& Osborne, L. N. (2004). An exploratory study of youth mentoring in an urban context: Adolescents' perceptions of relationship styles. Journal of Youth and Adolescence, 33(4), 293-306. https://doi.org/10.1023/B: JOYO.0000032638.85483.44

Lareau, A. (2003). Unequal childhoods: Class, race, and family life. University of California Press.

Lareau, A. (2015). Cultural knowledge and social inequality. American Sociological Review, 80(1), 1-27. https://doi.org/10.1177/0003122414565814

Legewie, N. M. (2016). Culture, narratives and upward educational mobility. In C. Timmermann, N. Clycq, M. McAndrew, A. Balde, L. Breakmans, \& S. Mels (Eds.), Youth in education. The necessity of valuing ethnocultural diversity (pp. 111-135). Routledge.

Legewie, N. M., \& Bohmann, S. (2018). Upward and downward social mobility probabilities have converged for men and women. DIW Weekly Report, 8(20), 169-178. https://doi.org/10.18723/diw_wb: 2018-20-1

Legewie, N. M., \& Tucci, I. (2021). Studying turning points in labour market trajectories-Benefits of a panel-based mixed methods design. Longitudinal and Life Course Studies, 12(1), 41-62. https://doi. org/10.1332/175795920X15949756176915

Lin, N., Ye, X., \& Ensel, W. M. (1999). Social support and depressed mood: A structural analysis. Journal of Health and Social Behavior, 40(4), 344-359. https:// doi.org/10.2307/2676330

Malecki, C. K., \& Demaray, M. K. (2003). What type of support do they need? Investigating student adjustment as related to emotional, informational, appraisal, and instrumental support. School Psychology Quarterly, 18(3), 231-252. https://doi.org/10.1521/scpq.18.3. 231.22576

Maton, K. I., Hrabowski, F. A., III, \& Greif, G. L. (1998). Preparing the way: A qualitative study of highachieving African American males and the role of the family. American Journal of Community Psychology, 26(4), 639-668.

Mayer, K. U. (2004). Whose lives? How history, societies, and institutions define and shape life courses. Research in Human Development, 1(3), 161-187.

Mayer, K. U. (2009). New directions in life course research. Annual Review of Sociology, 35(1), 413-433. https://doi.org/10.1146/annurev.soc.34. 040507.134619

McDonald, S., \& Lambert, J. (2014). The long arm of mentoring: A counterfactual analysis of natural 
youth mentoring and employment outcomes in early careers. American Journal of Community Psychology, 54(3/4), 262-273.

Modood, T. (2011). Capitals, ethnic identity and educational qualifications. In R. D. Alba \& M. C. Waters (Eds.), The new generation. New York University Press.

Morgan, S. L., \& Sørensen, A. B. (1999). Parental networks, social closure, and mathematics learning: A test of Coleman's social capital explanation of school effects. American Sociological Review, 64(5), 661-681. https://doi.org/10.2307/2657368

Portes, A., \& Fernández-Kelly, P. (2008). No margin for error: Educational and occupational achievement among disadvantaged children of immigrants. The ANNALS of the American Academy of Political and Social Science, 620(1), 12-36.

Putnam, R. D. (2007). E pluribus unum: Diversity and community in the twenty-first century. The 2006 Johan Skytte Prize Lecture. Scandinavian Political Studies, 30(2), 137-174. https://doi.org/10.1111/ j.1467-9477.2007.00176.x

Raiser, U. (2007). Erfolgreiche Migranten im deutschen Bildungssystem-Es gibt sie doch: Lebensläufe von Bildungsaufsteigern türkischer und griechischer Herkunft [Successful migrants in the German educational system-They do exist: Life courses of upwardly mobile students from Turkish and Greek families]. LIT.

Ream, R. K., \& Rumberger, R. W. (2008). Student engagement, peer social capital, and school dropout among Mexican American and non-Latino White students. Sociology of Education, 81(2), 109-139. https://doi. org/10.1177/003804070808100201

Smith, R. C. (2006). Mexican New York: Transnational lives of new immigrants. University of California Press.

Smith, R. C. (2014). Black Mexicans, conjunctural ethnicity, and operating identities: Long-term ethnographic analysis. American Sociological Review, 79(3), 1-32.

Sokatch, A. (2006). Peer influences on the collegegoing decisions of low socioeconomic status urban youth. Education and Urban Society, 39(1), 128-146. https://doi.org/10.1177/0013124506291783

Stanton-Salazar, R. D. (2001). Manufacturing hope and despair: The school and kin support networks of U.S.-Mexican youth. Teachers College Press.

Stanton-Salazar, R. D., \& Spina, S. U. (2003). Informal mentors and role models in the lives of urban Mexican-origin adolescents. Anthropology \& Education Quarterly, 34(3), 231-254.

Stanton-Salazar, R. D., \& Spina, S. U. (2005). Adolescent peer networks as a context for social and emotional support. Youth \& Society, 36(4), 379-417. https:// doi.org/10.1177/0044118X04267814

Tepecik, E. (2011). Bildungserfolge mit Migrationshintergrund: Biographien bildungserfolgreicher MigrantInnen türkischer Herkunft [Success in education among migrants: biographies of successful migrants from Turkey]. Springer.

Wuthnow, R. (2002). Religious involvement and statusbridging social capital. Journal for the Scientific Study of Religion, 41(4), 669-684. https://doi.org/10.1111/ 1468-5906.00153

Zhou, M., \& Kim, S. S. (2006). Community forces, social capital, and educational achievement: The case of supplementary education in the Chinese and Korean immigrant communities. Harvard Educational Review, 76(1), 1-29.

\section{About the Author}

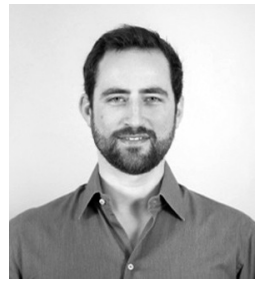

Nicolas M. Legewie is a visiting fellow at the Sociology Department of University of Pennsylvania. His research focuses on the role of social environments, such as personal and neighborhood networks, on educational and occupational attainment, and on upward mobility. He also writes and teaches about migration, the life course, research ethics, and research methodology such as video data analysis, mixed methods, digital social science research, and qualitative comparative analysis (QCA). 